\title{
Comparative study of essential oil constituents of Bupleurum species from Mongolia
}

\author{
Sh.Altantsetseg, S.Shatar, N.Javzmaa \\ Institute of Chemistry and Chemical Ttechnology, MAS \\ e-mail: altaa12000@yahoo.com
}

\begin{abstract}
Essential oils have been isolated from the Mongolian plant species Bupleurum scorzonerifolium Willd, Bupleurum sibiricum Vest and Bupleurum multinerve DC by a hydro distillation method. The compositions of the essentials oils were analyzed by GC and GC-MS methods. Indicating the following main constituents: limonene (15.21\%), p-cymene (11.54\%), (E)- $\beta$-ocimene (10.50\%), myrcene $(8.09 \%)$, sabinene $(6.56 \%), \alpha$-pinene $(6.33 \%)$, germacrene-D $(4.08 \%), \beta$-pinene $(3.13 \%), \delta$-cadinene $(2.73 \%)$, spathulenol $(2.71 \%)$ and caryophyllene oxide $(2.53 \%)$ for B.scorzonerifolium; caryophyllene oxide (16.97\%), spathulenol (7.25\%), pentodecane (6.33\%), $\alpha$-pinene (4.20\%), limonene (3.30\%), myrcene (3.09\%), cis-carvylacetate (1.69\%) and $\beta$-cubebene (1.43\%) for B.sibiricum; germacrene-D (19.41\%), (E)- $\beta$-ocimene (18.63\%), myrcene (9.13\%), limonene (7.81\%), E-caryophyllene (4.60\%), sabinene (2.80\%), $\beta$-elemene (2.72\%), bicyclogermacrene, $\beta$-pinene, $\gamma$-terpinene, $(Z)$ - $\beta$-ocimene $(2.00-2.10 \%)$, and caryophyllene oxide $(1.11 \%)$ for B.multinerve.
\end{abstract}

\section{Keywords: Bupleurum scorzonerifolium, B.sibiricum, B.multinerve (Apiaceae), essential oil} composition

\section{INTRODUCTION}

7 he genus Bupleurum is a very common wild growing perennial and 150 species of those originate from Euro-Asia[1]. The roots are collected in the spring and autumn of those bitter herbs are used in herbal medicine that contain rutin, quercetin, organic acids (oleic, linolenic, palmetic, stearic et al), stigmasterol and bupleuromol, as well as calcium and potassium[2.3].

The Bupleurum root is considered an herbal anti-inflammatory and antibacterial agent that may be useful for treating rheumatoid arthritis as well as it is a popular plant in traditional medical systems in Europe and Asia with reputation in treatment of chronic enlarged liver or spleen which are caused by chemicals and other hepatic affects, liver stasis, liver congestion, depression and irregular menstruation[5].

In Mongolian traditional therapy, the aerial parts of Bupleurum species are used in some cardiovascular diseases, in addition to infectious diseases ${ }^{4}$. A literature search is revealed many references of previous work those are on the essential oils of Bupleurum species[6-8].

Volatile components of Bupleurum scorzonerifolium and Bupleurum sibiricum from the Mongolian flora have been investigated $[9,10]$ previously, while there is no report on the volatile constituents of the aerial parts of Bupleurum multinerve.

The aim of this paper was to investigate the chemical compositions of the essential oils of B.scorzonerifolium, B.sibiricum and B.multinerve from the Mongolian forest-steppe region.

\section{EXPERIMENTAL}

Plant material. The aerial parts of the B.sibiricum Vest were collected from Zuunharaa of the Selenge aimag, B.multinerve DC and $B$. scorzonerifolium Willd were collected from Terelj, Hentii mountains in Mongolia 
during their flowering period in AugustSeptember, 2010. Voucher specimens were deposited in herbariums of the Botanical Institute of Mongolian Academy of Sciences, Ulaanbaatar, Mongolia.

Isolation of essential oil. The air-dried aerial parts of each plant species were hydro distilled in a Clevenger type apparatus[11] for $2 \mathrm{~h}$. The percentages of the essential oils were found to be $0.15 \%(\mathrm{w} / \mathrm{w})$ from B.scorzonerifolium, $0.24 \%(\mathrm{w} / \mathrm{w})$ from B.sibiricum and $0.35 \%$ (w/w) from B.multinerve respectively.

Gas chromatography analysis. About $15 \mathrm{mg}$ of essential oils of these 3 plants, which were dried with anhydrous sodium sulfate, were dissolved in $1 \mathrm{ml}$ of $\mathrm{CH}_{3} \mathrm{OH}$ and subjected to gas chromatography (GC). Analysis was performed on a HP 6890 plus Gas Chromatography (GC) equipped with a FID and fitted with HP-5 column $\quad(\mathrm{L}=25 \mathrm{~m} . \quad \mathrm{ID}=0.25 \mathrm{~mm}) . \quad$ The identification of constituents was established by comparison to retention times and MS spectra with those reported in the literature[12].

\section{RESULTS AND DISCUSSION}

The isolated essential oils from B.scorzonerifolium, B.sibiricum and B.multinerve were analyzed by gas chromatography and mass spectroscopy. The comparative study of chemical compositions of the essential oils of B.scorzonerifolium, B.sibiricum and B.multinerve from Mongolia are presented in Table I. As the results of monoterpenes and sesquiterpenes were revealed with a high amount in the essential oils of B.multinerve and B.scorzonerifolium as they grow in forest shadow and low lands. Furthermore, high amounts of the limonene $(15.21 \%)$ and ocimene $(10.5 \%)$ in the essential oil of B.scorzonerifolium make this essential oil more valuable than others. In contrast, the essential oil of B. sibiricum was rich in a high percentage of oxygenated sesquiterpenes. This fact might be explained that B. sibiricum usually grows in sunny places.
Table 1. Comparison of essential oil constituents of Bupleurum species from Mongolia

\begin{tabular}{|c|c|c|c|c|}
\hline \multirow[b]{2}{*}{ RT } & \multirow[b]{2}{*}{ Compounds } & \multicolumn{3}{|c|}{ Bupleurum } \\
\hline & & 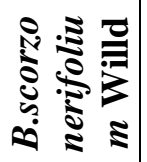 & 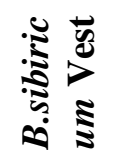 & 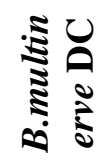 \\
\hline 800 & Hexanal & 0.65 & 1.12 & - \\
\hline 807 & ethyl acetate & - & 1.46 & - \\
\hline 867 & n-hexanol & - & 0.19 & - \\
\hline 931 & $\alpha$-thujene & $\mathrm{t}$ & 0.39 & 0.12 \\
\hline 939 & $\alpha$-pinene & 6.33 & 4.20 & 1.39 \\
\hline 953 & Camphene & 0.54 & 0.10 & 0.10 \\
\hline 969 & n-heptanal & $\mathrm{t}$ & $\mathrm{t}$ & $\mathrm{t}$ \\
\hline 976 & Sabinene & 6.56 & 0.20 & 2.80 \\
\hline 978 & octen-3-ol(1) & - & $\mathrm{t}$ & - \\
\hline 980 & $\beta$-pinene & 3.13 & 0.64 & 2.10 \\
\hline 991 & Myrcene & 8.09 & 3.09 & 9.13 \\
\hline 993 & octanol-3 & 0.1 & 0.33 & $\mathrm{t}$ \\
\hline 1018 & $\alpha$-terpinene & 0.33 & 0.10 & 0.10 \\
\hline 1026 & p-cymene & 11.54 & 1.68 & 0.80 \\
\hline 1031 & Limonene & 15.21 & 3.30 & 7.81 \\
\hline 1040 & $(\mathrm{Z})$ - $\beta$-ocimene & 1.00 & 0.27 & 2.00 \\
\hline 1050 & (E)- $\beta$-ocimene & 10.50 & 1.10 & 18.63 \\
\hline 1062 & $\gamma$-terpinene & 0.1 & 0.1 & 2.03 \\
\hline 1088 & Terpinolene & 0.34 & 0.31 & 0.10 \\
\hline 1095 & $\alpha$-pinene-oxid & $\mathrm{t}$ & - & - \\
\hline 1098 & Linalool & 0.1 & 1.63 & 0.1 \\
\hline 1143 & Camphor & - & - & 0.1 \\
\hline 1190 & methyl salicylate & 1.76 & - & - \\
\hline 1194 & Myrtenal & - & 0.20 & - \\
\hline 1204 & Verbanone & - & 0.20 & - \\
\hline 1217 & trans-carveol & 0.21 & 0.66 & 0.1 \\
\hline 1239 & cumin-aldehyde & 0.27 & $\mathrm{t}$ & $\mathrm{t}$ \\
\hline 1240 & Tridecane & - & 0.57 & - \\
\hline 1242 & Carvone & 0.49 & 0.35 & 0.1 \\
\hline 1257 & Myrtenol & $\mathrm{t}$ & $\mathrm{t}$ & $\mathrm{t}$ \\
\hline 1285 & bornylacetate & 0.36 & 0.57 & 0.21 \\
\hline 1291 & $\begin{array}{l}\text { E,E-2.4- } \\
\text { decadien }\end{array}$ & - & 0.36 & - \\
\hline 1351 & $\alpha$-cubebene & - & 1.16 & - \\
\hline & $\begin{array}{l}\text { Monoterpene } \\
\text { hydrocarbons }\end{array}$ & 66.01 & 15.48 & 47.11 \\
\hline & $\begin{array}{l}\text { Oxygenated } \\
\text { nonoterpenoids }\end{array}$ & 0.47 & 9.33 & 0.56 \\
\hline & Total (\%) & 66.48 & 24.81 & 47.67 \\
\hline
\end{tabular}




\begin{tabular}{|c|c|c|c|c|}
\hline \multirow[b]{2}{*}{ RT } & \multirow[b]{2}{*}{ Compounds } & \multicolumn{3}{|c|}{ Bupleurum } \\
\hline & & 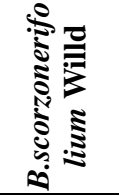 & 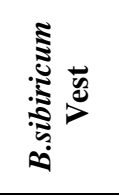 & 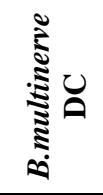 \\
\hline 1362 & cis-carvylacetate & 0.47 & 1.69 & 0.11 \\
\hline 1365 & nerylacetate & - & - & 0.13 \\
\hline 1376 & $\alpha$-copaene & 0.50 & 1.11 & 0.20 \\
\hline 1383 & geranylacetate & - & $\mathrm{t}$ & 0.10 \\
\hline 1390 & $\beta$-cubebene & 0.1 & 1.43 & 0.1 \\
\hline 1391 & $\beta$-elemene & 0.27 & 0.1 & 0.1 \\
\hline 1401 & methyleugenol & 0.1 & - & - \\
\hline 1407 & dodecanal & 1.41 & 0.1 & 1.56 \\
\hline 1418 & caryophyllene & 2.04 & 0.43 & 4.60 \\
\hline 1457 & $\alpha$-humulene & 0.77 & 0.1 & 1.40 \\
\hline 1458 & (E)- $\beta$-farnesene & 0.1 & 0.1 & 0.31 \\
\hline 1480 & germacrene-D & 4.08 & 0.1 & 19.41 \\
\hline 1485 & (E)-ionene & - & 0.32 & - \\
\hline 1493 & eqi-cubebol & 0.1 & 1.29 & 0.1 \\
\hline 1494 & bicyclogerman & 0.1 & 0.1 & 2.10 \\
\hline 1500 & dentodecane & 0.1 & 6.33 & 0.1 \\
\hline 1508 & E,E- $\alpha$-farnesene & 0.1 & 0.1 & 0.73 \\
\hline 1514 & cubebol & 0.1 & 0.97 & 0.1 \\
\hline 1524 & $\delta$-cadinene & 2.73 & 1.29 & 0.53 \\
\hline 1542 & $\alpha$-calocorene & - & $\mathrm{t}$ & - \\
\hline 1564 & E-nerolidol & 0.1 & 1.17 & 0.75 \\
\hline 1566 & spathulenol & 2.72 & 7.25 & 0.77 \\
\hline 1581 & caryophyllene oxide & 2.53 & 16.97 & 1.11 \\
\hline 1611 & tetradecanol & - & - & 0.41 \\
\hline 1627 & epi-cubenol & - & 0.64 & - \\
\hline 1653 & $\alpha$-cadinol & 0.1 & 0.1 & 0.78 \\
\hline 1700 & heptadecane & - & 0.46 & - \\
\hline 1762 & benzylbenzoate & - & 1.17 & - \\
\hline 2100 & heneicosane & - & 0.56 & - \\
\hline 2300 & tricosane & - & 0.49 & - \\
\hline & $\begin{array}{l}\text { Sesquiterpene } \\
\text { hydrocarbons }\end{array}$ & 2.73 & 6.86 & 32.64 \\
\hline & $\begin{array}{c}\text { Oxygenated } \\
\text { esquiterpenoids }\end{array}$ & 8.21 & 37.11 & 5.38 \\
\hline & Total (\%) & 10.94 & 44.02 & 38.02 \\
\hline
\end{tabular}

\section{CONCLUSIONS}

Our comparative study of the essential oils compositions of aerial parts of B.scorzonerifolium, B.sibiricum and B.multinerve shows that they differ by the contents of compositions which might be depended on plant species growing places and conditions. High percentage of limonene and ocimene in the essential oils of B.scorzonerifolium made them more valuable for treatment of diseases caused by bacteria. Moreover, the essential oil of this plant species can be used as a raw material of perfumes and hygienic products.

\section{ACKNOWLEDGEMENTS}

The authors acknowledge for the financial support given by the Mongolian Foundation for Science and Technology.

\section{REFERENCES}

1. Biological Encyclopedic dictionary. "Sovetskaya encyclopedia" Moscow. 1986. 104.

2. Grynevich M.A. // Journal Plant Resources 13 (2.3) 1977. 261, 421

3. Volhonskaya T.A. Investigation of flavonoids of the genus Bupleurum L from western Siberia. Synopsis of thesis by candidate biology of science. Tomsk. 1968. 19

4. Haydav Ts, Menshikova T.A. Medicinal plants in Mongolian traditional medicine. Ulaanbaatar, 1978. 191

5. Markova L.P et al. Wild growing useful plants of the Mongolian People's Republic. "Nauka" Leningrad. 1985. 13-15

6. Jimenez M.L, Osete M.A et al. Comparative study of different essential oils of Bupleurum gibraltaricum Lamarck. // Pharmazie. 44 (1989) 284

7. Martin S, Padilla E, Osete M.A et al. Antiinflammatory activity of the essential oil of Bupleurum fruticescens. // Planta medica 59 (1993) 533-535

8. Antonio Manunta et al. Secretary Tissues and Essential oil composition of Bupleurum fruticosum L. // J.Essent.Oil.Res. 4(1992) 461466

9. Shatar S. Chemical investigation of essential oils from the Mongolian flora. Issue I. Identification of essential oil components from the Mongolian flora by GC-MS. "Nauka" Ulaanbaatar. Mongolia. 1998. 116

10. International studies on the essential oils and bioactive constituents of aromatic and medicinal plants from Mongolia. Editors: N.Tsevegsuren, S.Shatar. Ulaanbaatar. 2009. 64-67

11. Adams P.R. Cedar wood oil-analysis and properties. In: Modern methods of plants analysis: oils and waxes. Berlin. 1991. 159-173

12. Adams P.R. Identification of essential oils by gas chromatography/mass spectroscopy. Allured Publ.Corp., Carol Stream.Illinois. 1995. 469 